\title{
Produktivitas Ulat Sutera (Bombyx mori L.) Ras BS-09 di Daerah Tropis
}

\author{
Silkworm Productivities of Bombyx mori L. BS-09 Race in Tropic \\ Y. Estetika ${ }^{1}, \&$ Y. C. Endrawati ${ }^{1}$ \\ ${ }^{1}$ Departemen Ilmu Produksi dan Teknologi Peternakan, Fakultas Peternakan, IPB \\ Jalan Agatis, Kampus IPB Dramaga Bogor 16680 \\ Email koresponden author: y.cahya82@gmail.com
}

\begin{abstract}
Silkworm is a cold-blooded animal (poikiloterm) so that environment conditions greatly affect their growth. In China, silkworms rearing in the highlands with cool conditions. However, Indonesia is a tropical country with diverse topography conditions and some of them are low altitude areas below 250 $\mathrm{m}$ above sea level (asl). This study examined the productivity of silkworms in altitude of $250 \mathrm{~m}$ asl. The material used silkworm seedlings from the Silkworm Breeding Center (PPUS) Soppeng and Candiroto, and using 2 different types of mulberry leaf feed (Morus multicaulis and Morus cathayana). Both PPUS have different climatic and altitude conditions. Soppeng at an altitude less than 300 meters asl and Candiroto at a higher one. The results showed that silkworm from Soppeng with fed M. multicaulis was significant different $(\mathbf{P}<\mathbf{0 . 0 5})$ than other treatments in almost all parameters (consumption, weight of larva, quantity and quality of cocoon shell). The result indicated silkworm Soppeng breed with $M$. multicaulis have good performance either cocoon shell productions and qualities in Tropic (especially rearing at altitudes around $250 \mathrm{~m}$ asl).
\end{abstract}

Keywords: Bombyx mori, Morus multicaulis, Morus cathayana, PPUS Soppeng, PPUS Candiroto

\section{PENDAHULUAN}

Ulat sutera termasuk Ordo Lepidoptera mencakup semua jenis kupu dan ngengat yang selama hidupnya mengalami siklus metamorfosis sempurna dari telur, larva, pupa, dan imago. Nilai ekonomi ulat sutera dimulai dari pemanfaatan kokon yang membungkus pupa sebagai sumber serat sutera. Usaha peternakan ulat sutera merupakan usaha yang memiliki prospek tinggi karena harga sutera yang relatif tinggi dibandingkan kain yang lain dan permintaan terhadap kain sutera pun cukup tinggi. Hanya saja potensi yang tinggi tersebut tidak diikuti oleh produksinya. Ketua Asosiasi Sutera Indonesia (ASSIA) (2014) menyatakan bahwa Indonesia hanya mampu memenuhi pasokan benang sutera dalam negeri sebesar 5\% dari total kebutuhan 900 ton/tahun, sedangkan $95 \%$ diimpor dari Cina.

Kemampuan produksi yang rendah tersebut, salah satunya disebabkan oleh produktivitas yang rendah. Faktorfaktor yang dapat mempengaruhi produktivitas ulat sutera antara lain adalah genetik dan lingkungan (Atmosoedarjo et al., 2000). Indonesia merupakan negara kepulauan dengan topografi wilayah yang beragam. Kepulauan Indonesia terdiri dari dataran rendah, dataran tinggi dan pegunungan. Keberagaman topografi tersebut menyebabkan tingkat produktivitas yang berbeda pada ulat sutera. Indonesia mempunyai dua Pusat Pembibitan Ulat Sutera (PPUS) di
Soppeng (Sulawesi Selatan) dan Candiroto (Jawa Tengah) yang menghasilkan ras BS-09. Ras tersebut merupakan hasil persilangan ras Cina dan Jepang yang diperuntukkan untuk peternak ulat sutera di Indonesia. Lingkungan di kedua PPUS cukup berbeda, suhu lingkungan di Soppeng tergolong tinggi dengan kisaran $28-32{ }^{\circ} \mathrm{C}$ dan kelembaban $61 \%-90 \%$ serta berada pada ketinggian 100-200 m dpl, sedangkan suhu di Candiroto tergolong rendah dengan kisaran $24-32{ }^{\circ} \mathrm{C}$ dan kelembaban $70 \%-95 \%$ serta berada pada ketinggian 575-600 m dpl (BMKG 2015).

Ulat sutera dari Soppeng mempunyai daya tahan yang lebih baik terhadap kondisi lingkungan panas dibandingkan bibit ulat sutera Candiroto karena produksi filamen atau serat suteranya lebih baik (Nursita 2008). Oleh sebab itu perlu kajian terhadap produktivitas ulat sutera dari kedua PPUS tersebut di daerah ketinggian rendah agar jumlah produksi serat sutera nasional dapat meningkat.

Nutrisi pakan ulat sutera merupakan salah satu faktor penting yang mempengaruhi pertumbuhan ulat sutera (Sunanto 1997). Pemeliharaan ulat sutera di PPUS Soppeng menggunakan pakan daun murbei jenis Morus multicaulis, sedangkan di PPUS Candiroto menggunakan $M$. cathayana. Kedua jenis murbei tersebut merupakan jenis pakan yang banyak digunakan peternak ulat sutera di Indonesia (Atmosoedarjo et al. 2000). Pada penelitian ini 
kedua jenis murbei tersebut juga diberikan pada bibit dari PPUS Soppeng dan Candiroto. Hal ini untuk mengkaji produktivitas ulat sutera unggul untuk daerah tropis.

\section{MATERI DAN METODE}

Penelitian ini menggunakan bibit ulat sutera $B$. mori ras BS-09 dari PPUS Soppeng dan Candiroto, masing-masing sebanyak 1200 ekor, serta pakan ulat sutera yaitu daun murbei M. multicaulis dan M. cathayana. Penelitian dilakukan di Laboratorium Non Ruminasia dan Satwa Harapan (NRSH), Departemen Ilmu Produksi dan Teknologi Peternakan, Fakultas Peternakan, Institut Pertanian Bogor.

\section{Prosedur}

\section{Persiapan Penelitian}

Prosedur penelitian dari persiapan hingga pelaksanaan merujuk pada Atmosoedarjo et al. (2000). Persiapan penelitian dimulai dengan disinfektan ruangan lima hari sebelum pemeliharaan ulat sutera. Disinfektan dengan penyemprotan larutan kaporit $(0,5 \%)$ keseluruh ruangan $\left(1-2 \mathrm{~L} / \mathrm{m}^{2}\right)$.

\section{Penetasan dan Pemindahan Ulat}

Telur didatangkan dari PPUS Soppeng dan Candiroto 10 hari sebelum ditetaskan. Ruang penetasan diatur pada kelembaban 75\%-80\% dan suhu $20-25{ }^{\circ} \mathrm{C}$. Ulat instar I-III dipelihara pada 12 kotak dengan kepadatan 200 ekor/ kotak dan ketika instar IV-V dipelihara pada 24 kotak. Ulat didesinfeksi tubuhnya dengan 0,5 g campuran 95\% kapur halus dan 5\% kaporit.

\section{Pemberian Pakan}

Daun murbei diberikan tiga kali sehari yaitu pagi, siang, dan sore. Daun murbei diiris sekitar $0,5-1,0 \mathrm{~cm}$, 1,5-2,0 $\mathrm{cm}$ dan 3,0-4,0 $\mathrm{cm}$ berturut-turut untuk instar I, II, dan III, sedangkan pada ulat instar IV dan V daun tidak dipotong-potong. Jumlah pakan yang diberikan pada instar I, II, III, IV, dan V berturut-turut 0,035; 0,129; 0,325; 2,400; dan 4,200 g/ekor/hari. Berat pakan yang diberikan dan sisa selalu ditimbang.

\section{Perlakuan saat Pergantian Kulit}

Ulat ditaburi campuran 95\% kapur dan 5\% kaporit setiap ganti kulit (molting). Jumlah campuran sekitar 0,5; 1,0; dan 1,5 g berturut-turut untuk pergantian instar I ke instar II, II ke III, III ke IV dan juga IV ke V. Penggantian alas dan pemberian desinfektan pada ulat kecil (instar I-III) dilakukan pada saat setelah ulat bangun, sedangkan pada fase ulat besar (instar IV-V) dilakukan setiap hari.

\section{Pengokonan}

Ulat yang akan mengokon diletakkan di seriframe dan kokon dipanen sekitar lima hari setelah ulat mengokon. Kokon yang dipanen dihitung yang normal dan cacat lalu ditimbang. Kokon dibersihkan dari floss lalu pupa dikeluarkan dengan cara menggunting kokon. Bobot floss, pupa, dan kulit kokon ditimbang dengan timbangan digital.

\section{Peubah.}

Peubah yang diamati adalah suhu dan kelembaban, konsumsi pakan, panjang dan lebar badan per instar, berat badan per instar, mortalitas per instar dan kualitas kokon yang meliputi persentase produksi kokon, persentase kokon cacat, berat kokon, berat pupa, berat floss, berat kulit kokon dan persentase kulit kokon.

\section{Rancangan Percobaan}

Penelitian ini menggunakan rancangan acak lengkap dengan pola faktorial $2 \times 2$. Faktor pertama sumber bibit ulat sutera (PPUS Soppeng dan Candiroto) dan faktor kedua jenis daun murbei (M. cathayana dan M. multicaulis). Tiap perlakuan mendapat tiga ulangan yang model matematikanya menurut Gaspersz (1991):

$$
Y i j k=\mu+\alpha i+\beta j+(\alpha \beta) i j+\varepsilon i j k
$$

Keterangan:

Yijk : nilai pengamatan pada ulangan ke-k dari sumber bibit ulat sutera ke-i yang diberi jenis daun murbei ke-j

$\mu \quad$ : nilai tengah umum pengamatan

ai : pengaruh sumber bibit ulat sutera ke-i (Candiroto dan Soppeng)

$\beta \mathrm{j} \quad$ : pengaruh jenis daun murbei ke-j (M. cathayana dan M. multicaulis)

$(\alpha \beta)$ ij : pengaruh interaksi antara sumber bibit ulat sutera ke-i dan jenis daun murbei ke-j

\&ijk : pengaruh galat percobaan pada ulangan ke-k dari bibit ulat sutera ke-i yang diberi jenis daun murbei ke-j

Data yang diperoleh dianalisis dengan Analysis of Varians (ANOVA) dan setiap analisis yang memberikan hasil beda nyata dilanjutkan dengan uji Tukey.

\section{HASIL DAN PEMBAHASAN}

\section{Kondisi Umum Tempat Penelitian}

Ulat sutera merupakan serangga berdarah dingin yang sangat tergantung pada kondisi lingkungan seperti suhu dan kelembaban. Toleransi serangga terhadap suhu lingkungan sekitar $1-2{ }^{\circ} \mathrm{C}$ dari suhu optimum hidupnya (Triplehorn dan Johnson 2005). Pada ketinggian sekitar $250 \mathrm{~m}$ dpl suhu dan kelembaban cenderung lebih rendah dibandingkan pada daerah di atas $250 \mathrm{~m}$ dpl. Rataan suhu dan kelembaban ruang pemeliharaan di ketinggian $250 \mathrm{~m}$ dpl disajikan pada Tabel 1 .

Hasil penelitian menunjukkan bahwa suhu pemeliharaan pada fase ulat kecil (instar I-III) berkisar $26-27^{\circ} \mathrm{C}$ dengan kelembaban berkisar $77 \%-80 \%$ (Tabel 1). Kisaran suhu ruang pemeliharaan fase ulat kecil sudah optimum karena masuk kisaran standar pemeliharaan ulat kecil yaitu $\left(26-28{ }^{\circ} \mathrm{C}\right)$, namun kelembaban lebih rendah daripada kelembaban optimum (80\%-90\%) (Nunuh dan Andikarya 2006). Hal tersebut dikarenakan jendela ventilasi terbuka lebar dan angin terlalu kencang sehingga air dilantai ruang pemeliharaan cepat menguap. Untuk menjaga kelembaban, ventilasi jendela ruangan jangan terlalu terbuka atau lantai ruang pemeliharaan dipercik air secara rutin jika ventilasi terbuka lebar (Andadari 2003).

Suhu pada ruang pemeliharaan instar IV lebih tinggi daripada suhu optimum $\left(24-25{ }^{\circ} \mathrm{C}\right)$, kelembaban juga 
Estetika et al.

Jurnal Ilmu Produksi dan Teknologi Hasil Peternakan 6 (3): 104-112

Tabel 1. Rataan suhu dan kelembaban ruang pemeliharaan

\begin{tabular}{|c|c|c|c|c|}
\hline \multirow[t]{2}{*}{ Peubah } & \multirow[t]{2}{*}{ Waktu } & \multirow{2}{*}{$\begin{array}{c}\text { Instar I-III } \\
\text { Rataan } \pm \text { SD } \\
\end{array}$} & \multirow{2}{*}{$\frac{\text { Instar IV }}{\text { Rataan } \pm \text { SD }}$} & \multirow{2}{*}{$\begin{array}{c}\text { Instar V } \\
\text { Rataan } \pm \text { SD }\end{array}$} \\
\hline & & & & \\
\hline Suhu $\left({ }^{\circ} \mathrm{C}\right)$ & Pagi & $26,48 \pm 0,51$ & $26,00 \pm 0,60$ & $26,70 \pm 0,79$ \\
\hline \multirow{5}{*}{ Kelembaban (\%) } & Siang & $27,38 \pm 0,54$ & $26,60 \pm 0,70$ & $28,28 \pm 0,92$ \\
\hline & Sore & $27,34 \pm 0,39$ & $26,70 \pm 0,80$ & $28,18 \pm 1,09$ \\
\hline & Pagi & $79,11 \pm 2,26$ & $81,90 \pm 1,20$ & $75,20 \pm 6,16$ \\
\hline & Siang & $77,50 \pm 2,83$ & $81,60 \pm 3,20$ & $71,75 \pm 7,03$ \\
\hline & Sore & $80,00 \pm 1,87$ & $81,60 \pm 2,60$ & $72,25 \pm 7,19$ \\
\hline
\end{tabular}

Keterangan : Waktu pengamatan pagi (07.00), siang (12.00) dan sore (17.00) pada bulan Januari-Februari 2015

lebih tinggi daripada kelembaban optimum (75\%). Suhu pada pemeliharaan instar $\mathrm{V}$ lebih tinggi daripada suhu optimum $\left(23-24^{\circ} \mathrm{C}\right)$, kelembaban juga lebih tinggi daripada kelembaban optimum (70\%) (Nunuh dan Andikarya 2006). Hal ini terjadi karena tempat pemeliharaan berada di daerah dengan ketinggian tempat yang rendah sedangkan syarat hidup optimum untuk ulat sutera secara umum berada di daerah dengan ketinggian wilayah di atas $500 \mathrm{~m} \mathrm{dpl}$. Ketinggian wilayah menentukan kondisi lingkungan seperti suhu dan kelembaban. Semakin tinggi suatu wilayah maka kecenderungan suhu makin rendah, dan sebaliknya di daerah dengan ketinggian rendah mempunyai kecenderungan suhu makin tinggi.

Suhu dan kelembaban di tempat penelitian masuk dalam kisaran suhu dan kelembaban daerah Soppeng (suhu $28-32^{\circ} \mathrm{C}$ dan kelembaban 61\%-90\%). Suhu dan kelembaban di Candiroto yang merupakan salah satu asal sumber bibit ulat sutera pada penelitian ini tergolong rendah yaitu 24-32 ${ }^{\circ} \mathrm{C}$ dengan kelembaban 70\%-95\% (BMKG 2015).

\section{Konsumsi Pakan}

Konsumsi diperoleh dari selisih antara berat daun murbei yang diberikan pada awal instar dan yang tersisa pada akhir instar. Konsumsi pakan ulat sutera pada kelima instar selama penelitian disajikan pada Tabel 2. Konsumsi pakan instar I dan II hanya dipengaruhi oleh salah satu perlakuan yaitu sumber bibit ulat atau jenis murbei, sedangkan pada instar III, IV dan V lebih dipengaruhi dari sumber bibit dan jenis murbei.

Konsumsi ulat asal Soppeng lebih tinggi daripada Candiroto. Hal ini dikarenakan kondisi iklim tempat penelitian hampir sama dengan asal daerah bibit Soppeng, sehingga ulat dari bibit Soppeng lebih tahan terhadap suhu lingkungan yang lebih tinggi. Oleh karenanya kebutuhan energi yang terserap akan lebih banyak. Konsumsi ulat yang diberi $M$. multicaulis juga lebih tinggi dari M. cathayana. Hal ini karena daun $M$. multicaulis memiliki bentuk yang besar membulat dibandingkan dengan bentuk daun $M$. cathayana yang kecil dan berlekuk-lekuk.

Tabel 2. Konsumsi pakan ulat sutera instar I-IV yang berasal dari sumber bibit dan pakan berbeda

\begin{tabular}{|c|c|c|c|c|}
\hline \multirow[t]{2}{*}{ Instar } & \multirow[t]{2}{*}{ Jenis Pakan } & \multicolumn{2}{|c|}{ Sumber Bibit } & \multirow[t]{2}{*}{ Rataan } \\
\hline & & Candiroto & Soppeng & \\
\hline & \multicolumn{4}{|c|}{ g/ekor/hari } \\
\hline \multirow[t]{3}{*}{ I } & M. cathayana & $0,013 \pm 0,006$ & $0,023 \pm 0,006$ & $0,018 \pm 0,007$ \\
\hline & M. multicaulis & $0,017 \pm 0,006$ & $0,023 \pm 0,006$ & $0,020 \pm 0,006$ \\
\hline & Rataan & $0,015 \pm 0,005 b$ & $0,023 \pm 0,005 \mathrm{a}$ & \\
\hline \multirow[t]{3}{*}{ II } & M. cathayana & $0,096 \pm 0,006$ & $0,103 \pm 0,006$ & $0,100 \pm 0,006 b$ \\
\hline & M. multicaulis & $0,110 \pm 0,000$ & $0,113 \pm 0,006$ & $0,111 \pm 0,004 \mathrm{a}$ \\
\hline & Rataan & $0,103 \pm 0,008$ & $0,108 \pm 0,007$ & \\
\hline \multirow[t]{3}{*}{ III } & M. cathayana & $0,187 \pm 0,006$ & $0,247 \pm 0,015$ & $0,217 \pm 0,034 b$ \\
\hline & M. multicaulis & $0,210 \pm 0,020$ & $0,277 \pm 0,006$ & $0,243 \pm 0,039 a$ \\
\hline & Rataan & $0,198 \pm 0,018 b$ & $0,262 \pm 0,019 \mathrm{a}$ & \\
\hline \multirow[t]{3}{*}{ IV } & M. cathayana & $2,125 \pm 0,065$ & $2,193 \pm 0,043$ & $2,159 \pm 0,062 b$ \\
\hline & M. multicaulis & $2,243 \pm 0,040$ & $2,295 \pm 0,005$ & $2,269 \pm 0,038 \mathrm{a}$ \\
\hline & Rataan & $2,184 \pm 0,081 b$ & $2,244 \pm 0,062 \mathrm{a}$ & \\
\hline \multirow[t]{3}{*}{ V } & M. cathayana & $3,883 \pm 0,043$ & $4,042 \pm 0,033$ & $3,963 \pm 0,093 b$ \\
\hline & M multicaulis & $3,957 \pm 0,038$ & $4,090 \pm 0,035$ & $4,023 \pm 0,079 \mathrm{a}$ \\
\hline & Rataan & $3,920 \pm 0,054 b$ & $4,066 \pm 0,040 \mathrm{a}$ & \\
\hline
\end{tabular}

Keterangan: Angka yang disertai huruf berbeda pada baris atau kolom yang sama menunjukkan hasil yang berbeda nyata $(\mathrm{P}<0,05)$ 
Atmosoedarjo et al. (2000) menyatakan bahwa ulat sutera mengkonsumsi daun murbei dengan cara mengerip dan menggigit pinggiran daun sehingga bentuk daun yang lebar dan besar perlu diberikan.

Pertambahan Panjang dan Lebar Larva

Panjang dan lebar larva merupakan salah satu faktor yang dapat digunakan untuk menentukan produktivitas ulat sutera. Hasil pengukuran panjang dan lebar badan ulat disajikan pada Tabel 3. Bibit ulat Soppeng dengan pakan M. multicaulis mempunyai rataan panjang dan lebar badan (instar I sampai V) lebih tinggi dibandingkan perlakuan yang lain karena konsumsi bibit Soppeng dengan pakan M. multicaulis lebih tinggi dibanding dengan perlakuan yang lain. Bibit Soppeng lebih tahan terhadap suhu dan kelembaban tinggi dibandingkan bibit Candiroto karena kondisi kisaran suhu dan kelembaban tempat penelitian masuk dalam kisaran suhu dan kelembaban wilayah Soppeng.

Purwanti (2007) menyatakan kondisi suhu dan kelembaban mempengaruhi pertumbuhan ulat. Suhu dan kelembaban yang tidak berada pada kisaran kebutuhan ulat, akan menyebabkan ulat kurang nafsu makan, dan kekurangan makan sehingga menyebabkan ulat mudah terserang penyakit dan pertumbuhannya menjadi terhambat.

Rataan panjang dan lebar ulat sutera (instar I sampai V) dalam penelitian ini lebih kecil dibandingkan panjang dan lebar ulat penelitian Prabu et al. (2011) (Tabel 3). Hal ini terjadi karena ulat sutera yang dipelihara hanya diberikan pakan berupa daun murbei M. multicaulis dan M. cathayana, sedangkan pada penelitian Prabu et al. (2011) pakan diberi tambahan vitamin dan kondisi lingkungan berada pada kondisi optimum untuk pertumbuhan ulat sutera.

Berdasarkan Gambar 1 dan 2 dapat dilihat bahwa ulat sutera bibit Soppeng yang diberi pakan $M$. multicaulis (batang warna biru) mempunyai ppb dan plb yang lebih tinggi dibanding perlakuan lain. Hal ini dikarenakan konsumsi pakannya juga lebih tinggi dibandingkan dengan perlakuan lainnya. Pertambahan panjang dan lebar badan ulat sutera sangat berpengaruh terhadap pertambahan berat badan ulat sutera karena digunakan sebagai indikator keberhasilan pertumbuhan fase larva pada ulat sutera.

Tabel 3. Rataan panjang dan lebar larva ulat sutera B. mori dari sumber bibit dan jenis pakan berbeda instar I-V

\begin{tabular}{|c|c|c|c|c|c|c|c|}
\hline \multirow{3}{*}{ Instar } & \multirow{3}{*}{ Jenis Murbei } & \multicolumn{4}{|c|}{ Sumber Bibit } & \multirow{2}{*}{\multicolumn{2}{|c|}{ Rataan }} \\
\hline & & \multicolumn{2}{|c|}{ Candiroto } & \multicolumn{2}{|c|}{ Soppeng } & & \\
\hline & & Panjang (mm) & Lebar (mm) & Panjang (mm) & Lebar (mm) & Panjang (mm) & Lebar (mm) \\
\hline \multirow{5}{*}{ I } & M. cathavana & $5.613=0.178$ & $1.187=0.075$ & $5.790 \pm 0.399$ & $1.230=0.072$ & $5.702 \pm 0.293$ & $1.208=0.070$ \\
\hline & M. multicaulis & $5.827 \pm 0.395$ & $1.160 \pm 0.104$ & $6.047 \pm 0.189$ & $1.130 \pm 0.095$ & $5.937 \pm 0.302$ & $1.145 \pm 0.091$ \\
\hline & Rataan & $5.720 \pm 0.298$ & $1.173=0.082$ & $5.918=0.313$ & $1.180=0.093$ & & \\
\hline & $\mathrm{KK}(\%)$ & 6.3 & 8.54 & 6.09 & 8.47 & 6.19 & 8.5 \\
\hline & Prabu $\approx a l .(2011)$ & & & & & 7 & 1.5 \\
\hline \multirow[t]{5}{*}{ III } & M. cathavana & $11.083=0.270$ & $1.653=0.042$ & $11.500=0.144$ & $1.870=0.098$ & $11.292 \pm 0.299$ & $1.762 \pm 0.136$ \\
\hline & M. multicaulis & $11.930=0.630$ & $1.930=0.046$ & $11.520=0.390$ & $1.947=0.127$ & $11.725=0.519$ & $1.938=0.086$ \\
\hline & Rataan & $11.507 \pm 0.635$ & $1.792=0.156$ & $11.510=0.263$ & $1.908=0.109$ & & \\
\hline & $\mathrm{KK}(\%)$ & 4.83 & 0 & 3.01 & 7.4 & 3.92 & 3.7 \\
\hline & Prabv $\&$ al. (2011) & & & & & 11 & 2.5 \\
\hline \multirow[t]{5}{*}{ III } & M. cathavana & $20.450=0.212$ & $2.967 \pm 0.104$ & $20.583=0.399$ & $2.787=0.122$ & $20.517=0.295$ & $2.923=0.157$ \\
\hline & M. multicaulis & $20.900=0.183$ & $2.880 \pm 0.213$ & $21.047 \pm 0.263$ & $2.800 \pm 0.087$ & $20.973=0.218$ & $2.793=0.095$ \\
\hline & Rataan & $20.675=0.303$ & $2.877 \pm 0.142$ & $20.815=0.394$ & $2.840=0.152$ & & \\
\hline & $\mathrm{KK}(\%)$ & 1.08 & 6.85 & 1.86 & 3.58 & 1.47 & 5.21 \\
\hline & Prabu $\approx a l .(2011)$ & & & & & 16 & 3.5 \\
\hline \multirow[t]{5}{*}{ IV } & M. cathavana & $34.343=0.350$ & $4.633=0.211$ & $34.410 \pm 0.869$ & $4.803=0.150$ & $34.377 \pm 0.594$ & $4.718=0.188$ \\
\hline & M. multicaulis & $36.477 \pm 0.216$ & $4.797 \pm 0.032$ & $35.217 \pm 0.661$ & $4.783=0.136$ & $35.847 \pm 0.818$ & $4.790=0.089$ \\
\hline & Rataan (\%) & $35.410 \pm 1.197$ & $4.715=0.162$ & $34.813=0.820$ & $4.793=0.128$ & & \\
\hline & $\mathrm{KK}$ & 0.94 & 3.67 & 2.55 & 3.61 & 1.74 & 3.64 \\
\hline & Prabve a al. (2011) & & & & & 57 & 5.3 \\
\hline \multirow[t]{5}{*}{$\mathrm{V}$} & M. cathavana & $44.267 \pm 0.879$ & $6.117 \pm 0.132$ & $59.827 \pm 1.414$ & $7.183=0.160$ & $52.047 \pm 8.587$ & $6.650 \pm 0.598$ \\
\hline & M. multicaulis & $45.573=0.566$ & $6.353=0.032$ & $59.360=0.580$ & $7.307 \pm 0.046$ & $52.467 \pm 7.569$ & $6.830=0.523$ \\
\hline & Rataan & $44.920=0.974$ & $6.235=0.155$ & $59.593 \pm 1.000$ & $7.245=0.125$ & & \\
\hline & $\mathrm{KK}(\%)$ & 1.9 & 1.6 & 2.09 & 1.95 & 1.99 & 1.77 \\
\hline & Prabv a al. (2011) & & & & & 70 & 10 \\
\hline
\end{tabular}




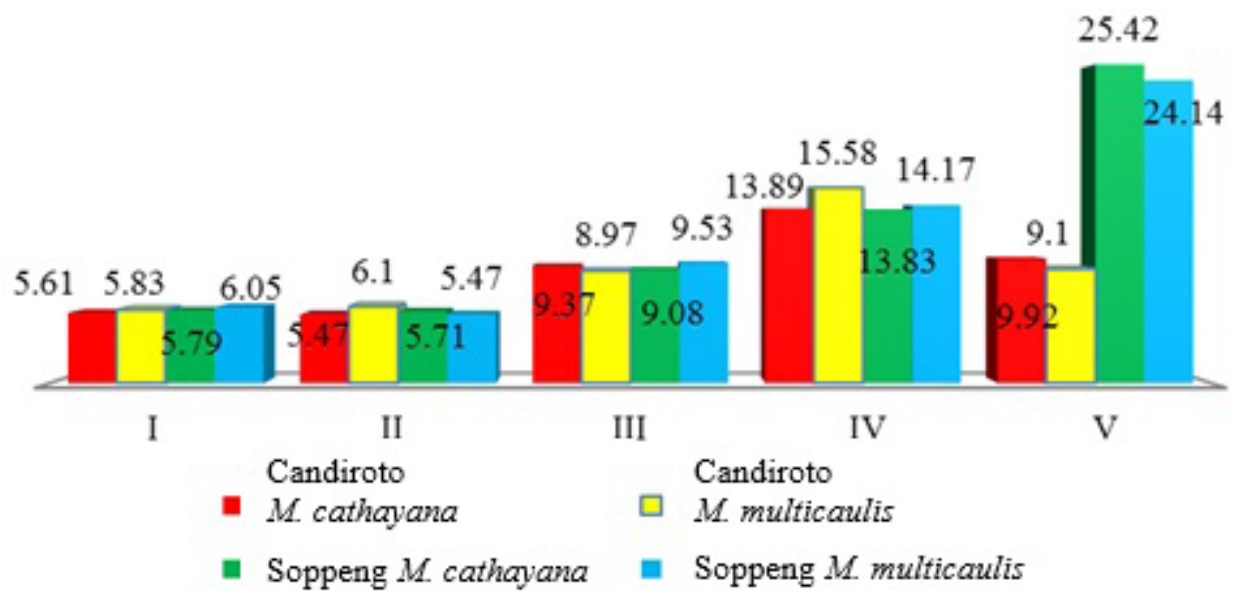

Gambar 1. Digram pertambahan panjang badan (ppb) ulat sutera B. mori

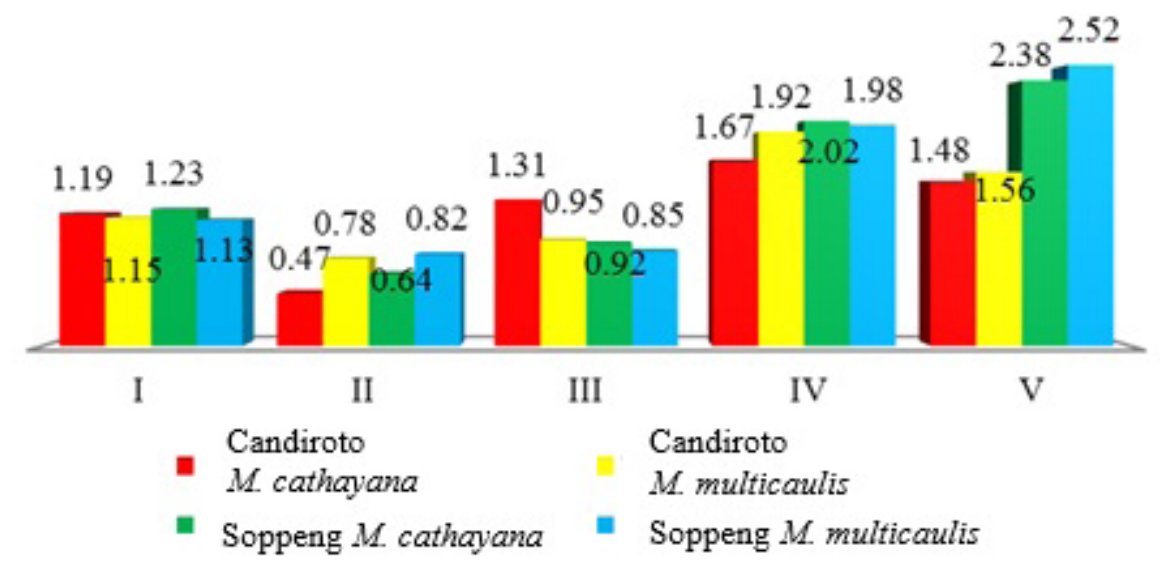

Gambar 2. Diagram pertambahan lebar badan (plb) ulat sutera B. mori

\section{Berat Larva}

Berat larva ulat sutera merupakan faktor penting dalam menentukan kualitas kokon dan pembentukan serat sutera. Hasil berat ulat sutera disajikan pada Tabel 4. Berat ulat sutera dalam penelitian ini dipengaruhi oleh sumber bibit dan jenis pakan, kecuali pada instar IV tidak berpengaruh nyata $(\mathrm{P}>0,05)$ (Tabel 4). Bibit Soppeng memiliki berat larva yang lebih tinggi dibandingkan bibit Candiroto. Hal yang sama didapatkan pada jenis pakan $M$. multicaulis, berat ulat yang dihasilkan juga lebih tinggi daripada $M$. cathayana. Hal ini dikarenakan konsumsi ulat sutera pada pakan $M$. multicaulis lebih tinggi. Andadari (2003) menyatakan bahwa konsumsi pakan yang tinggi akan meningkatkan berat larva ulat sutera.

\section{Mortalitas}

Mortalitas merupakan salah satu indikator keberhasilan pemeliharaan. Mortalitas ulat sutera yang berasal dari sumber bibit ulat dan diberi pakan yang berbeda pada instar I-V disajikan pada Gambar 3. Data persentase mortalitas tertinggi terjadi pada instar III (Gambar 3). Hal ini karena pada instar III kotak pemeliharaan terlalu padat akibat ukuran ulat yang semakin bertambah namun masih dipelihara dalam luasan kotak pemeliharaan yang sama dengan ulat instar I dan II. Akibatnya kondisi di dalam kotak pemeliharaan menjadi lebih tinggi suhunya dan lembab yang berakibat ulat banyak yang mati. Selain itu persaingan dalam konsumsi pakan juga menjadi penyebab ulat banyak mati. Samsijah \& Kusumaputera (1975) daya tahan hidup ulat sutera banyak dipengaruhi oleh faktor lingkungan terutama kelembaban selama pemeliharaan. Pada instar III (Gambar 3) juga terlihat bahwa bibit dari Candiroto (batang kuning) mempunyai persentase mortalitas yang paling tinggi karena toleransi suhu dan kelembaban yang lebih rendah dibanding bibit Soppeng.

Pada instar V juga menunjukkan terdapat mortalitas yang cukup tinggi namun lebih rendah dibandingkan instar III. Hal ini terjadi karena suhu dan kelembaban lingkungan tinggi sehingga mengakibatkan ulat gagal mengokon. Atmosoedarjo et al. (2000) menyatakan bahwa fase instar V merupakan fase pelepasan air sehingga untuk pemeliharaan instar $\mathrm{V}$ harus berada pada lingkungan kering dan tidak lembab. 
Estetika et al.

Jurnal Ilmu Produksi dan Teknologi Hasil Peternakan 6 (3): 104-112

Tabel 4. Berat ulat sutera B. mori yang berasal dari sumber dan diberi pakan yang berbeda pada instar I-V

\begin{tabular}{|c|c|c|c|c|}
\hline \multirow[t]{2}{*}{ Instar } & \multirow[t]{2}{*}{ Jenis Pakan } & \multicolumn{2}{|c|}{ Sumber Bibit } & \multirow[t]{2}{*}{ Rataan } \\
\hline & & Candiroto & Soppeng & \\
\hline & & & & \\
\hline \multirow[t]{3}{*}{ I } & M. cathayana & $0,005 \pm 0,000$ & $0,007 \pm 0,000$ & $0,006 \pm 0,001 \mathrm{~b}$ \\
\hline & M. multicaulis & $0,005 \pm 0,000$ & $0,008 \pm 0,000$ & $0,006 \pm 0,001 \mathrm{a}$ \\
\hline & Rataan & $0,005 \pm 0,000 \mathrm{~b}$ & $0,007 \pm 0,000 \mathrm{a}$ & \\
\hline \multirow[t]{3}{*}{ II } & M. cathayana & $0,031 \pm 0,001$ & $0,038 \pm 0,003$ & $0,034 \pm 0,003$ \\
\hline & M. multicaulis & $0,030 \pm 0,002$ & $0,038 \pm 0,001$ & $0,034 \pm 0,004$ \\
\hline & Rataan & $0,031 \pm 0,001 b$ & $0,037 \pm 0,002 \mathrm{a}$ & \\
\hline \multirow[t]{3}{*}{ III } & M. cathayana & $0,160 \pm 0,010$ & $0,160 \pm 0,000$ & $0,160 \pm 0,006 \mathrm{~b}$ \\
\hline & M. multicaulis & $0,170 \pm 0,010$ & $0,177 \pm 0,006$ & $0,173 \pm 0,008 \mathrm{a}$ \\
\hline & Rataan & $0,165 \pm 0,010$ & $0,168 \pm 0,009$ & \\
\hline \multirow[t]{3}{*}{ IV } & M. cathayana & $0,757 \pm 0,136$ & $0,723 \pm 0,071$ & $0,740 \pm 0,099$ \\
\hline & M. multicaulis & $0,750 \pm 0,010$ & $0,763 \pm 0,042$ & $0,757 \pm 0,028$ \\
\hline & Rataan & $0,753 \pm 0,086$ & $0,743 \pm 0,056$ & \\
\hline \multirow[t]{3}{*}{ V } & M. cathayana & $1,800 \pm 0,098 \mathrm{c}$ & $3,11 \pm 0,133 \mathrm{a}$ & $2,453 \pm 0,723$ \\
\hline & M. multicaulis & $2,027 \pm 0,031 \mathrm{c}$ & $2,72 \pm 0,513 b$ & $2,377 \pm 0,385$ \\
\hline & Rataan & $1,913 \pm 0,140 \mathrm{~b}$ & $2,917 \pm 0,227 \mathrm{a}$ & \\
\hline
\end{tabular}

Keterangan : Angka yang disertai huruf berbeda pada baris atau kolom yang sama menunjukkan hasil yang berbeda nyata $(\mathrm{P}<0,05)$

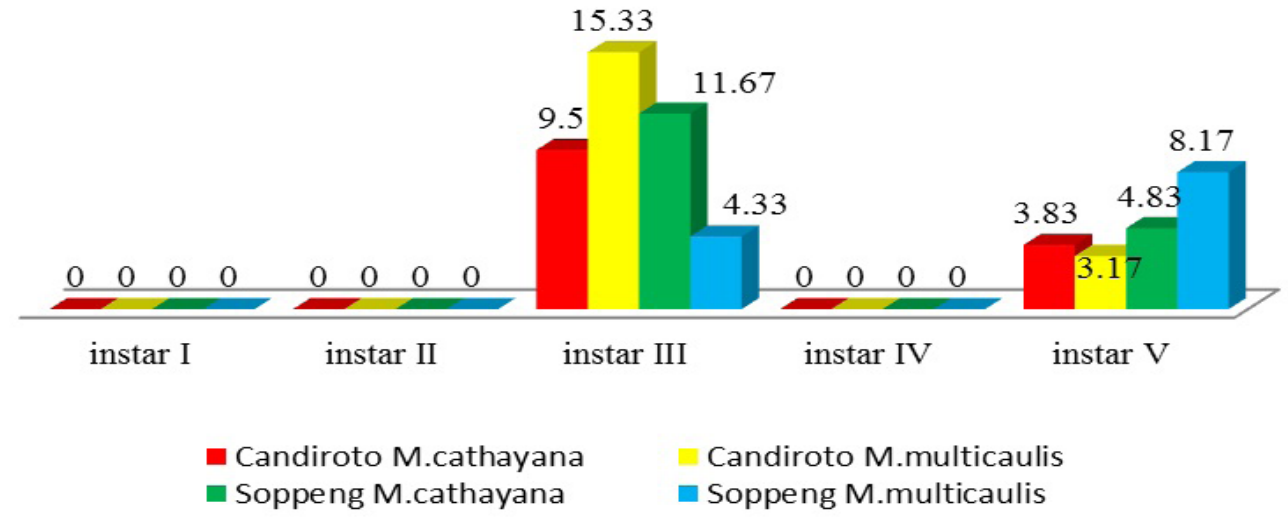

Gambar 3. Diagram persentase mortalitas ulat sutera

\section{Persentase Produksi Kokon}

Pengokonan dan panen kokon merupakan tahap akhir dalam pemeliharaan ulat sutera. Persentase produksi kokon yang dihasilkan disajikan pada Tabel 5. Produksi kokon ulat yang mendapat pakan $M$. cathayana lebih rendah dan beragam (Tabel 5), karena pada instar III ulat sutera yang mendapat pakan $M$. cathayana memiliki mortalitas yang tinggi, sehingga jumlah ulat pada awal instar $\mathrm{V}$ sudah berkurang dibanding ulat yang mendapat pakan M. multicaulis. Selain itu, pada bibit Soppeng memiliki produksi kokon yang lebih tinggi dari Candiroto karena suhu dan kelembaban termasuk kisaran Soppeng. Oleh karenanya bibit Candiroto memiliki waktu pengokonan yang berbeda pada saat mengokon dan terdapat larva yang mati pada saat proses pengokonan akibat tidak toleran terhadap suhu dan kelembaban di lingkungan pemeliharaan. Atmosoedarjo et al. (2000) menyatakan bahwa suhu dan kelembaban berpengaruh terhadap produksi kokon.

\section{Kualitas Kokon B. mori}

Beberapa peubah kualitas kokon ada yang dipengaruhi oleh sumber bibit ulat dan jenis murbei. Tidak ada yang dipengaruhi oleh interaksi kedua faktor tersebut seperti yang disajikan pada Tabel 6. Pemilihan sumber bibit dan jenis pakan yang sesuai didasarkan pada kualitas kokon yang dihasilkan. Andadari (2003) menyatakan bahwa standar kualitas kokon adalah berdasarkan berat kokon, persentase kulit kokon dan persentase kokon cacat.

\section{Persentase Kokon Cacat}

Persentase kokon cacat yang dihasilkan hanya dipengaruhi oleh sumber bibit. Bibit Soppeng memiliki nilai yang lebih rendah dibandingkan bibit Candiroto (Tabel 6). Hal ini dikarenakan suhu dan kelembaban termasuk kisaran Soppeng sehingga ulat dari Candiroto mengalami waktu pengokonan yang tidak sama. Kokon cacat dapat disebabkan oleh proses pengokonan yang tidak sempurna di dalam seriframe 
Estetika et al.

Jurnal Ilmu Produksi dan Teknologi Hasil Peternakan 6 (3): 104-112

Tabel 5. Persentase produksi kokon ulat sutera B. mori yang berasal dari sumber dan jenis pakan yang berbeda

\begin{tabular}{|c|c|c|c|}
\hline \multirow[t]{2}{*}{ Jenis Pakan } & \multicolumn{2}{|c|}{ Sumber Bibit } & \multirow[t]{2}{*}{ Rataan } \\
\hline & Candiroto & Soppeng & \\
\hline \multicolumn{4}{|c|}{$(\%)$} \\
\hline M. cathayana & $35,39 \pm 11,17$ & $36,19 \pm 19,21$ & $35,79 \pm 14,06 b$ \\
\hline M. multicaulis & $76,53 \pm 7,72$ & $85,16 \pm 7,83$ & $80,85 \pm 8,41 \mathrm{a}$ \\
\hline Rataan & $55,96 \pm 24,11$ & $60,68 \pm 29,86$ & \\
\hline
\end{tabular}

Keterangan : Angka yang disertai huruf berbeda pada baris atau kolom yang sama menunjukkan hasil yang berbeda nyata $(\mathrm{P}<0,05)$

sehingga bentuk kokon tidak normal. Beberapa penyebab bentuk yang tidak normal dalam penelitian antara lain kelebihan cairan yang menempel di kokon sehingga kokon tidak berwarna putih bersih, waktu panen yang kurang tepat, waktu pengokonan yang kurang tepat, ulat yang sedang proses mengokon mati sehingga mengotori kokon bagian dalam. Atmosoedarjo et al. (2000) ulat yang siap mengokon harus segera dipisahkan ke tempat pengokonan agar tidak terganggu oleh ulat yang belum siap mengokon, ulat yang sakit pada umumnya tidak akan mencapai tahap pupa sehingga membuat kokon bagian dalam kotor. Apabila waktu panen kokon terlambat maka kokon akan rusak karena sudah berlubang untuk tempat keluarnya ngengat.

\section{Berat Kokon}

Berat kokon tidak nyata dipengaruhi oleh sumber bibit ulat, jenis murbei maupun interaksi keduanya, yaitu rata-rata 0,971 g/butir (Tabel 6). Berat kokon yang dihasilkan lebih kecil dibandingkan dengan standar berat kokon menurut Atmosoedarjo et al. (2000), yaitu 1,5-1,8 g/butir untuk varietas murni dan 2,0-2,5 g/butir untuk hibrida. Berat kokon rendah karena pemberian konsumsi pakan berdasarkan acuan dari Atmosoedarjo et al. (2000) yang berada pada lingkungan optimum, sedangkan lingkungan tempat pemeliharaan termasuk ke dalam lingkungan bersuhu rendah sehingga terjadi penurunan dalam membentuk serat sutera dan berat kokon yang dihasilkan tidak optimal.

\section{Berat Pupa}

Hasil menunjukkan bahwa berat pupa hanya dipengaruhi oleh sumber bibit (Tabel 6). Bibit Soppeng memiliki berat pupa yang lebih besar dibandingkan Candiroto karena berat larvanya pada instar $\mathrm{V}$ juga lebih tinggi. Berat pupa sangat dipengaruhi oleh berat larva pada instar V (Nursita 2008). Menurut Atmosoedarjo et al. (2000) yang menyatakan bahwa perubahan dari larva pada instar V menjadi pupa terlihat pertama kali dengan berhentinya makan dengan ditandai oleh ekdisis dari kulit, larva berubah menjadi kokon.

Tabel 6. Kualitas kokon ulat sutera B. mori dari sumber bibit dan jenis pakan yang berbeda

\begin{tabular}{|c|c|c|c|c|}
\hline \multirow[t]{2}{*}{ Peubah } & \multirow[t]{2}{*}{ Jenis Pakan } & \multicolumn{2}{|c|}{ Sumber Bibit } & \multirow[t]{2}{*}{ Rataan } \\
\hline & & Candiroto & Soppeng & \\
\hline \multirow[t]{3}{*}{ Persentase kokon cacat (\%) } & M. cathayana & $15,582 \pm 7,599$ & $1,802 \pm 3,121$ & $8,692 \pm 9,163 \mathrm{a}$ \\
\hline & M. multicaulis & $2,974 \pm 2,421$ & $0,000 \pm 0,000$ & $1,487 \pm 2,236 \mathrm{a}$ \\
\hline & Rataan & $9,278 \pm 8,522 \mathrm{a}$ & $0,901 \pm 2,207 \mathrm{~b}$ & \\
\hline \multirow[t]{3}{*}{ Berat kokon (g) } & M. cathayana & $1,003 \pm 0,108$ & $1,030 \pm 0,272$ & $1,017 \pm 0,186$ \\
\hline & M. multicaulis & $1,093 \pm 0,070$ & $0,757 \pm 0,065$ & $0,925 \pm 0,194$ \\
\hline & Rataan & $1,048 \pm 0,095$ & $0,893 \pm 0,232$ & 0,971 \\
\hline \multirow[t]{3}{*}{ Berat pupa (g) } & M. cathayana & $0,167 \pm 0,006$ & $0,357 \pm 0,012$ & $0,262 \pm 0,104$ \\
\hline & M. multicaulis & $0,200 \pm 0,035$ & $0,380 \pm 0,050$ & $0,290 \pm 0,106$ \\
\hline & Rataan & $0,183 \pm 0,029 b$ & $0,368 \pm 0,035 \mathrm{a}$ & \\
\hline \multirow[t]{3}{*}{ Berat floss (g) } & M. cathayana & $0,020 \pm 0,010$ & $0,017 \pm 0,006$ & $0,018 \pm 0,007$ \\
\hline & M. multicaulis & $0,010 \pm 0,000$ & $0,013 \pm 0,006$ & $0,012 \pm 0,004$ \\
\hline & Rataan & $0,015 \pm 0,008$ & $0,015 \pm 0,005$ & 0,015 \\
\hline \multirow[t]{3}{*}{ Berat kulit kokon (g) } & M. cathayana & $0,100 \pm 0,020$ & $0,167 \pm 0,025$ & $0,133 \pm 0,042$ \\
\hline & M. multicaulis & $0,117 \pm 0,021$ & $0,163 \pm 0,031$ & $0,140 \pm 0,034$ \\
\hline & Rataan & $0,108 \pm 0,020 \mathrm{~b}$ & $0,165 \pm 0,025 \mathrm{a}$ & \\
\hline \multirow[t]{3}{*}{ Persentase kulit kokon (\%) } & M. cathayana & $10,067 \pm 2,303$ & $17,561 \pm 7,846$ & $8,692 \pm 9,163$ \\
\hline & M. multicaulis & $10,624 \pm 1,255$ & $21,830 \pm 5,179$ & $1,487 \pm 2,236$ \\
\hline & Rataan & $10,345 \pm 1,687 b$ & $19,696 \pm 6,389 a$ & \\
\hline
\end{tabular}

Keterangan: Angka yang disertai huruf berbeda pada baris atau kolom yang sama menunjukkan hasil yang berbeda nyata $(\mathrm{P}<0,05)$ 


\section{Berat Floss}

Hasil data menunjukkan bahwa berat floss tidak dipengaruhi oleh sumber bibit ulat, jenis murbei maupun interaksi keduanya, yaitu rata-rata $0,015 \mathrm{~g} /$ butir. Floss merupakan serat sutera yang berfungsi sebagai penyangga kokon sehingga beratnya lebih dipengaruhi oleh tempat pengokonan dibanding sumber bibit maupun jenis pakan. Andadari (2003) menyatakan bahwa ulat akan berputarputar mencari tempat pengokonan yang baik dan dipilihnya kemudian membuat lapisan kokon tipis-tipis pada saat mengokon. Atmosoedarjo et al. (2000), kokon yang telah dipanen masih diselimuti oleh serabut serat sutera (floss) yang apabila dibiarkan akan mengasorbsi air dari udara dan menurunkan mutu kokon.

\section{Berat dan Persentase Kulit Kokon}

Berat kulit kokon dipengaruhi oleh sumber bibit yakni bibit Soppeng nyata lebih tinggi dibanding Candiroto dengan rata-rata $0,165 \mathrm{~g}$ (Tabel 6). Hal ini karena saat instar $\mathrm{V}$, bibit Soppeng mempunyai konsumsi yang tinggi yaitu 4,066 g/ekor dengan berat ulat yang tinggi yaitu 2,917 g sehingga meskipun menghasilkan pupa yang lebih berat, juga menghasilkan serat kokon yang tinggi. Baskoro (2008) menyatakan bahwa semakin tinggi berat kulit kokon, maka semakin besar kandungan seratnya. Berat kulit kokon pada penelitian ini lebih kecil dari hasil Atmosoedarjo et al. (2000) yaitu 0,30-0,40 g untuk berat kulit kokon varietas murni dan 0,35-0,55 g untuk varietas hibrida. Hal tersebut dapat terjadi karena suhu rata-rata pada saat penelitian adalah $26-28{ }^{\circ} \mathrm{C}$ dengan kelembaban $71 \%-75 \%$. Suhu tempat pemeliharaan lebih tinggi dari standar sehingga dapat mempengaruhi berat kulit kokon yang dihasilkan.

Hasil penelitian Atmosoedarjo et al. (2000) ulat sutera yang akan mengokon sebaiknya mendapat suhu 23-25 ${ }^{\circ} \mathrm{C}$, dan kelembaban $60 \%-75 \%$. Hartati dan Umar (2012) berpendapat bahwa terdapat beberapa faktor yang mempengaruhi berat kulit kokon yaitu, kemampuan memproduksi serat setiap ulat berbeda, jenis ulat, jumlah dan kualitas pakan yang dikonsumsi, suhu serta kelembaban saat mengokon.

Persentase kulit kokon dipengaruhi oleh sumber bibit saja, yakni nyata lebih tinggi pada bibit yang berasal dari Soppeng yaitu sebesar 19,69\% (Tabel 6). Hasil menyatakan bahwa persentase kulit kokon berbanding lurus dengan berat kulit kokonnya. Berat kulit kokon Soppeng tinggi sehingga persentase kulit kokonnya juga tinggi. Persentase kulit kokon Soppeng sudah sesuai dengan standar menurut Atmosoedarjo et al. (2000) yaitu berkisar antara 18\%-22\%. Persentase kulit kokon dapat dipengaruhi oleh berat kulit kokon dan berat kokon segar. Nursita (2008) berpendapat bahwa nilai persentase kulit kokon erat hubungannya dengan persentase filamen kokon.

\section{KESIMPULAN}

Sumber bibit yang berasal dari Soppeng dengan kombinasi pemberian pakan daun murbei jenis $M$. multicaulis memberikan hasil performa produksi kokon dan kualitas kokon yang baik dipelihara di daerah tropis.

\section{DAFTAR PUSTAKA}

Andadari, L. 2003. Pengenalan dan Penanganan Ulat Sutera. Hardjosworo PS. Departemen Pendidikan Nasional, Bogor.

Anwar, A. 1992. Penggunaan Pospol dan Kaporit sebagai Bahan Desinfeksi Tubuh Ulat terhadap Produksi Kokon. Balai Persutraan Alam Direktorat Jenderal Reboisasi dan Rehabilitasi Lahan, Ujung Padang.

Atmosoedarjo, S., J. Kartasubrat, M. Kaomini, W. Saleh, W. Moerdoko, Pramoedibyo, \& S. Ranoeprawiro. 2000. Sutera Alam Indonesia. Yayasan Sarana Wana Jaya, Jakarta.

Baskoro, A. 2008. Karakteristik kulit kokon yang berasal dari perkebunan teh di daerah purwakarta. Skripsi. Bogor (ID): Institut Pertanian Bogor.

BMKG (Badan Meteorologi Klimatologi dan Geofisika). 2015. Prakiraan Cuaca Indonesia. Badan Meteorologi Klimatologi dan Geofisika, Jakarta.

Gaspersz, V. 1991. Teknik Analisis dalam Penelitian Percobaan. Tarsito, Bandung.

Hartati, Umar. 2012. Pengaruh pemberian jenis murbei Morus multicaulis dan Morus cathayanaterhadap produksi kokon ulat sutera (Bombyx mori L) varietas lokal, Jepang, Cina, dan Rumania. Jurnal Sainsmat. $1(1): 1-12$.

Hidayah, N. I. 2012. Pertumbuhan ulat sutera (Bobyx mori L) hibrid baru dan jenis komersial [skripsi]. Bogor (ID): Institut Pertanian Bogor.

Kasip, M. L. 2001. Pembentukan galur baru ulat sutera (Bombyx mori L) melalui persilangan ulat sutera bivoltin dan polivoltin. Disertasi. Bogor (ID): Institut Pertanian Bogor

Nunuh, A., O. Andikarya. 2006. Budidaya Ulat Sutera Alam (Bombyx mori L). Politeknik VEDCA Joint Program dengan Politeknik Negeri Jember, Cianjur.

Nursita, I. 2008. Perbandingan produktivitas ulat sutera dari dua tempat pembibitan yang berbeda pada kondisi lingkungan pemeliharaan panas. Jurnal Ilmu-Ilmu Peternakan. 21(3): 1-17.

Prabu, G., S. Selvi, V. Mathivanan, M. Pradhap, \& T. Vivekananthan. 2011. Studies on the comparative feed efficacy of Bombyx mori (L) (lepidoptera: bombycidae) fed with silver nanoparticles (agnps) and spirulina treated MR2 mulberry leaves in relation to growth and development. International Journal of Pharma and Bio Sciences. 2(4): 183-186.

Purwanti, R. 2007. Respon pertumbuhan dan kualitas kokon ulat sutera (Bombyx mori L) dengan rasio pemberian pakan yang berbeda. Skripsi. Bogor (ID): Institut Pertanian Bogor.

Rangaswami, G., M. N. Narasimhana, \& M. S. Yolly. 1976. 
Mulberry cultivation manual on sericulture. Agriculture Seri Bulletin. 14(1): 51-54.

Samsijah, Kusumaputera. 1975. Pemeliharaan Ulat Sutera (Bombyx mori L). Kertas Kerja pada Kongres Biologi IV. Lembaga Penelitian Hutan, Bogor.
Sunanto, H. 1997. Budidaya Murbei dan Usaha Persuteraan Alam. Kanisius, Yogyakarta.

Triplehorn, C.A, N. F. Johnson. 2005. Borror's Introduction to The Study of Insect 7th Edition. Thomson Brooks/ Cole, USA. 